\title{
Art Addressing Consumerism in the Age of Late Capitalism
}

\author{
POLONA TRATNIK \\ Faculty for Slovene and International Studies, \\ New University, Ljubljana, Slovenia
}

\begin{abstract}
The globalized world is still in the phase of late capitalism, signified by the establishment of multinational corporations, globalized markets and work, mass consumerism and the fluid flow of capital. The question of the criticism of art towards the capitalist system, its ideology and consumerism is therefore still current and is readdressed in this contribution. Considering this issue, the recurrent theoretical reference is American materialist aesthetician Fredric Jameson, who was among the first to define culture and art in the context of late capitalism. In the article the author revises Jameson's critique of art addressing consumerism and demonstrates that he did not consider the relevance of the means of consumption as regards the cultural logic of late capitalism. She claims that in order to open space to examine contemporary art as being critical towards consumerism, one also needs to consider the ontological changes that have occurred to art and pay attention to performative art, while Jameson was still focused on a representational mode of art. By being performative and also setting out actions outside of spaces that were traditionally designed for art, in the space meant for consumption, art has much a better chance to act politically, which Jameson wished to see from art which addresses consumerism, but did not. The author argues that if one is to seek critical or political art in late capitalism, those would be the cases of artistic interventions into the means of consumption.
\end{abstract}

Keywords: Late capitalism; contemporary art; means of consumption.

The globalized world is still in the phase of late capitalism as defined by Ernst Mandel, signified by the establishment of multinational corporations, globalized markets and work, mass consumerism and the 
fluid flow of capital, which has taken place from the 1960s onwards (Mandel 1972). The question of art's criticism towards the capitalist system, its ideology and consumerism is therefore still current. Considering this issue, the recurrent theoretical reference is American materialist aesthetician Fredric Jameson, who was among the first to define culture and art in the context of late capitalism. His theory on postmodernism has gained such theoretical relevance that it has not yet been replaced by any other more current theory of similar or comparable importance. I will therefore revise Jameson's critique of art which addresses consumerism. The deconstruction of this influential theory is important in order to open space to examine the functioning of the means of consumption, to borrow the term from Georg Ritzer, and the critical potential of artistic intervention into these means. In order to do that, we need to consider the ontological changes through which art has gone and pay attention to performative art, while Jameson, on the other hand, was still focused on a representational mode of art. By being performative and also by setting out actions outside of spaces traditionally designed for art, one can assert that art has a much better chance of engaging in political action in the public space.

\section{Art as the Unconcealment of the Truth}

According to the observation of the renowned Fredric Jameson, popart as art that appears in the phase of late capitalism reflects commodity fetishism but fails to develop criticism. He recognizes

one of the central issues about postmodernism itself and its possible political dimensions: Andy Warhol's work in fact turns centrally around commodification, and the great billboard images of the Coca-Cola bottle or the Campbell's soup can, which explicitly foreground the commodity fetishism of a transition to late capital, ought to be powerful and critical political statements. If they are not that, then one would surely want to know why, and one would want to begin to wonder a little more seriously about the possibilities of political or critical art in the postmodern period of late capital. (Jameson 1991: 9)

In his observation of consumerism, Jameson examines the problem of commodification. Objects are transformed into commodities and are fetishized. This holds true not only for Coca-Cola, but for human subjects as well. Stars such as Marilyn Monroe are transformed into images of themselves. Jameson is focused on the works of art as artifacts. He does not, therefore, for instance, acknowledge that artists such as Andy Warhol, whose work he discussed, have themselves become fetishized commodities. Instead of broadening his perspective on commodity fetishism, he approached the works of art as if they were still the "consecrated" objects meant for contemplation. Because Warhol's paintings obviously don't have this function, he sees them as works of art which are hollow and poor. This perspective is supported by his recognition that a feature of postmodernism is a new depthlessness. He acknowl- 
edges "intensities", which are free-floating and euphoric and which are in accordance with the spirit of consumerism. In contrast, modernism praised depth, living context, space for the observer who had a possibility to supplement the work of art. Loneliness, social fragmentation and isolation were expressed and the world of anxiety and alienation was revealed. Instead of deep expressions and existential themes, postmodernism shows and repeats the fetishism of consumer goods and its ubiquity. The situation is comparable to an addiction, "with a whole historically original consumers' appetite for a world transformed into sheer images of itself and for pseudoevents and "spectacles"' (Jameson 1991: 18). Such objects are "simulacrum", that is "the identical copy for which no original has ever existed" (Jameson 1991: 18). Parody and speaking in a dead language are significant for postmodernism. Modernism, on the other hand, is characterized by originality and the search for truth. Jameson refers to Martin Heidegger and his study of Van Gogh's painting A Pair of Shoes (1886) to outline the characteristics of postmodernism (in art) by comparing Van Gogh's and Warhol's shoes.

For Heidegger art is the "setting-into-work of truth" (Heidegger 1993: 199). He studies the case of the painted peasant shoes and ascertains: "Van Gogh's painting is the disclosure of what the equipment, the pair of peasant shoes, is in truth." (Heidegger 1993: 161) The truth as addressed by Heidegger means "the unconcealment of beings" which the Greek called alêtheia (Heidegger 1993: 161). "If there occurs in the work a disclosure of a particular being, disclosing what and how it is, then there is here an occurring, a happening of the truth at work" (Heidegger 1993: 161-162) in the work of art. Heidegger deliberately chose a commonly found equipment-a pair of peasant's shoes, which is a mere thing, a self-contained thing like a block of granite is a material in a definite form. Then he took Van Gogh's painting of the pair of peasant's shoes to articulate the significance of the work of art representing the pair of shoes:

From the dark opening of the worn inside of the toilsome tread of the worker stares forth. In the stiffly rugged heaviness of the shoes there is the accumulated tenacity of her slow trudge through the far-spreading and ever-uniform furrows of the field swept by raw wind. On the leather lie the dampness and richness of the soil. /.../ This equipment is pervaded by uncomplaining worry as to the certainty of bread. (Heidegger 1993: 159)

There is a meaningful difference between the mere thing and the work of art. Everything that the peasant's shoes are is to be found in the painting. "The peasant woman, on the other hand, simply wears them." (Heidegger 1993: 160) Art is thus understood essentially as the agent unconcealing the truth. The work of art presents it. At the same time, what art is "should be inferable from the work." (Heidegger 1993: 144) There is work invested in the work of art that makes it a work. Heidegger sees art as essentially artifactual. In addition, this thingly element, as Heidegger called it, actually refers to the sensual character of art. "The thingly element is so irremovably present in the artwork that 
we are compelled rather to say conversely that the architectural work is in stone, the carving is in wood, the painting in color, the linguistic work in speech, the musical composition in sound." (Heidegger 1993: 145) At this point we recall Georg W. F. Hegel's consideration that "art presents itself to sense, feeling, intuition, imagination” (Hegel 1975: 5). The beautiful has its being in "pure appearance" (Hegel 1975: 4). "But appearance itself is essential to essence. Truth would not be truth if it did not show itself and appear" (Hegel 1975: 8). Hegel required the freedom of art. Art in general can serve other ends and in this sense is a mere passing amusement. This required autonomy of art, its freedom, makes fine art "truly art, and it only fulfils its supreme task when it has placed itself in the same sphere as religion and philosophy, and when it is simply one way of bringing to our minds and expressing the Divine, the deepest interests of mankind, and the most comprehensive truths of the spirit." (Hegel 1975: 7) For Hegel, art assures a special kind of appearance through which it communicates what is "inherently true" (Hegel 1975: 8). Art is a special kind of representation for both Hegel as well as Heidegger. For Hegel, even if it subordinates itself to serious aims and produces serious effects, the means that art uses for this purpose is deception (Hegel 1975: 4). The "representations of art" are "a deceptive appearance"; truer representations would be of historiography, however, the content of the latter

remains burdened with the entire contingency of ordinary life and its events, complications, and individualities, whereat the work of art brings before us the eternal powers that govern history without this appendage of the immediate sensuous present and its unstable appearance. (Hegel 1975: 9)

For Heidegger, truth is the truth of Being. "Beauty does not occur apart from this truth. When truth sets itself into the work, it appears. Appearance-as this kind of being of truth in the work and as work-is beauty. Thus the beautiful belongs to truth's propriative event." (Heidegger 1993: 206) In Heidegger's view, art has such high status that the truth can or even must happen as art. Yet, he concludes the discussion on the origin of the work of art with a reference to Hegel's question which "remains: Is art still an essential and necessary way in which that truth happens which is decisive for our historical existence, or is art no longer of this character?" (Heidegger 1993: 205).

Jameson finally answers this question in a way with his criticism of popart, which actually appears in direct opposition to what Heidegger and Hegel comprehended as art. Popart and the whole culture of postmodernism, as observed by Jameson, do not assure any unconcealment of the truth, they don't create any such representations. Pop art products are not "works" in the Heideggerian sense; they are simulacrums.

Appropriately enough, the culture of the simulacrum comes to life in a society where exchange value has been generalized to the point at which the very memory of use value is effaced, a society of which Guy Debord has observed, in an extraordinary phrase, that in it 'the image has become the final form of commodity reification.' (Jameson 1991: 18) 
Jameson is focused on the problem of the image and its representational ability, whereas, according to his observation, pop art fails to present the truth in the manner as Van Gogh's painting represents the peasant shoes by communicating the truth about the life, the everyday struggles and worries of the peasant. Warhol's paintings, according to Jameson, don't stand for any kind of truth or reality they would aim to unconceal. They are "empty" signifiers, bare images oriented only towards themselves.

The way Jameson understood Van Gogh's paintings is accordant with Guy Debord's comprehension of images in the society of the spectacle: "Everything that was directly lived has receded into a representation." (Debord 1989: 7). This does not mean that the images follow and depict reality. Debord placed stress on the fragmentation of views that takes place with the flood of images, which finally establishes a separate "pseudo-world". Therefore: "The spectacle is a concrete inversion of life, an autonomous movement of the nonliving." (Debord 1989: 7). The simulacrum is conceptualized as an illusion of reality, wherein the signifier no longer refers to reality. Yet, the criticism of images has relevant ground in Plato's criticism of images as substitutes for the real things. According to the Platonian perspective images are to be examined in relation to the truth. Images have a secondary status in this regard, as they are not real or true, therefore also not, as formulated by Susan L. Feagin "as powerful as the original, and so they are condemned as being weak imitations of the real thing, with a correlative tendency to confuse us about the nature of truth and reality" (Feagin 1995: 267). Yet Feagin contributed an important argument against this assertion that images are weaker than the original, namely she claimed that "substitutes extend the power of the original" by making the signified being present in different places at once, such as the emperor in every province, the Virgin Mary on every altar, ancestors in every vestibule, the president in every post office. Ludwig Feuerbach (1841) noticed the power of images, which is based on widening the gap between the signifier and the referent and which inverts the relevance of the original in favor of the copy: "But certainly for the present age, which prefers the sign to the thing signified, the copy to the original, fancy to reality, the appearance to the essence, this change, inasmuch as it does away with illusion, is an absolute annihilation, or at least a reckless profanation; for in these days illusion only is sacred, truth profane." (Feuerbach 1855: 10) This remark of Feuerbach that truth has become profane and the illusion sacred anticipated the notion of the simulacrum as conceptualized by Jean Baudrillard: "Neofiguration is an invocation of resemblance, but at the same time the flagrant proof of the disappearance of objects in their very representation: hyperreal. Therein objects shine in a sort of hyperresemblance /.../ that makes it so that fundamentally they no longer resemble anything, except the empty figure of resemblance, the empty form of representation" (Baudrillard 1994: 45). 
As regards the showing of art works to the public, Jameson did not pay attention to the exhibiting environment in which art is to take place. Here, there is a relevant difference between the ever-present images and the spaces appropriate for showing art. These spaces create conditions for certain devotion and to perform a ritual to experience art, which holds some religious qualities of experiencing art. Walter Benjamin, one of the scholars of the Frankfurt school, linked traditional sorts of artwork, such as paintings, to the cult, magic and religion: "Originally, the embeddedness of an artwork in the context of tradition found expression in a cult. As we know, the earliest artworks originated in the service of rituals-first magical, then religious. And it is highly significant that the artwork's auratic mode of existence is never entirely severed from its ritual function" (Benjamin 2008: 24). Feagin considered paintings to be the ones to have the transformative power for the spaces to become ritualistic places: "paintings transform the space, and place, where they are, into one where certain ritual observances are appropriate" (Feagin 1995: 265). It could be added however that paintings also have a sort of transformative power for the observers, which is particularly effective if they are shown in spaces that establish better conditions to bring this power to effect. Precisely for this reason, to enable the enforcement of this power which is supported by the ritual, modernism established the gallery as a white cube. The white cube is still the appropriate space for showing Warhol's paintings. The ideology of the gallery as the white box was profoundly analyzed by Brian O'Doherty (first in 1976). The white, ideal space is an archetypical image of art in the $20^{\text {th }}$ century. It comprises some of the sacredness of the church, formality of the court hall and mysticism of the experimental laboratory, and is set in an elegant design, which all together establish a unique chamber of aesthetics. The ideal gallery extracts any hint that testifies to its artfulness from the work of art. The work is in a white box isolated from everything that would draw the observer's attention away from the art on display (O'Doherty 2000). The purposeful gallery thus creates an ideological context that enables the objects exhibited there to become consecrated as the works of art. The art gallery also supports the ritual of experiencing art and of the contemplation of the works of art. In such a manner the artistic context establishes the conditions for the truth to happen through the work of art. It seems that such were also Jameson's expectations, as he was shocked by the flatness of Warhol's paintings.

Heidegger was aware of the proper way to present such works of art as he appreciated, which is to exhibit them. This means that how art is presented is not irrelevant. This setting up, however, does not mean a bare placing. Setting up a work is "an erecting that consecrates and praises", "the work opens up a world and keeps it abidingly in force" (Heidegger 1993: 169). Exhibition establishes conditions for the consecration of the works of art. Heidegger recognizes the analogy between 
the sacred temples and art exhibitions. The spaces of art consolidate the sacredness of art and invite people to perform rituals of the appreciation of art. The work of art opens up a world at the exhibition as well as the temple opens up a world. "The temple-work, standing there, opens up a world and at the same time sets this world back again on earth" (Heidegger 1993: 168). The temple comprises sacredness: "By means of the temple, the god is present in the temple" (Heidegger 1993: 167).

One aspect of the end of art, addressed by Hegel and Heidegger, but also by Jameson, can be related to the withdrawal of the sacredness related to art and its enjoyment. Jameson actually determined this has happened with pop art. Consumerism as a theme entered the world of art. In addition, the works of art have themselves become fetishized commodities par excellence (Tratnik 2019). This is another effect of consumerism that Jameson did not recognize. But art also moved out of the context of art into other public spheres and into the centers of consumption. In order that this could become possible, art had to change its ontological status from being the representational means for unconcealing the truth to becoming an action, a performance, an intervention. Not only have changes occurred to the institution of art, the religious moment has found its place in the increasingly growing centers of consumption. These facts open up space for quite different considerations about consumerism and art in late capitalism.

\section{Art as Intervention into the Temples of Consumption}

In his study of postmodernism as the cultural logic of late capitalism, Jameson noted that it was from architectural debates that his own conception of postmodernism initially began to emerge (Jameson 1991: 2). In architecture, postmodernism stages itself as aesthetic populism, which has at least the merit to efface the high-modernist frontier between high culture and commercial culture (Jameson 1991: 2). Although interested in consumerism as the central feature of late capitalism, Jameson, however, does not examine how the means of consumption seduce the consumer and how shopping malls organize people's behavior. He is not interested in the consumer's experience of shopping, the milieu in which consumption takes place, consumers' psychology, their shopping addiction, and the ideology at work in the places of consumption. All these are the actual grounds that establish the cultural logic and the success of late capitalism. At about the same time that Jameson first published his theory of postmodernism (in 1984), American theologian Ira G. Zepp analyzed shopping malls as ceremonial centers (Zepp 1986). Zepp acknowledged that in the urban USA (of that time, in the 1980s) people continue to seek community, construct centered spaces and ritualize their lives, this time through shopping malls. These comprise mythic geometry, architectural rhetoric and offer a meaningful variety of human activities that take place there. Even earlier than Zepp, in 1980, cultural anthropologist Alexander Moore analyzed Walt 
Disney World as a ritual space and a playful pilgrimage center. Moore ascertained that Walt Disney World organizes behavior by combining play and ritual, which "comprise a metaprocess of expressive behavior rooted in our mammalian past." (Moore 1980: 207) The ritualization of the lives of the majority of people in late capitalism has not only fundamentally evolved around consumerism. The means of consumption have become the "cathedrals of consumption", ascertained George Ritzer and he points out the "quasi-religious, 'enchanted' nature of such new settings" (Ritzer 2005: x). He establishes that people make "pilgrimages" to these places, "in order to practice our consumer religion" (Ritzer 2005: x). These means of consumption are structured to have enchanted, even sacred, religious character-sociologist Peter Corrigan acknowledged that "the Church and industry can draw upon the same awe-inspiring techniques" and recognized "department stores as similar to cathedrals" (Corrigan 1997: 56). They are immense, vast gigantic, with huge galleries and staircases inside the buildings and enable to look down into the vast and bustling throng. Corrigan compares the effects of the architecture of the sites of consumption with architecture of the church: "size is a characteristic of many buildings that are designed to awe small human creatures" (Corrigan 1997: 55). The other relevant idea emphasized by Corrigan regarding shopping malls is that they provide everything. He links this idea to the "broader notions of power: rulers who really can provide everything will forever have people in their debt, and a department store may well borrow some of the same effect" (Corrigan 1997: 55). Suddenly such a place "almost magically abolishes all thought of deficits or shortages" (Corrigan 1997: 55).

Ritzer further establishes that shopping malls have become "more than commercial and financial enterprises; they have much in common with the religious centers of traditional civilizations" (Ritzer 2005: 8). People are enthusiastically part of consumer society and these settings offer the "greatest spectacle" (Ritzer 2005: xi). Because we can easily grow bored, the consumptions settings compete to see "which one can put on the greatest show" (Ritzer 2005: xi). Not only shopping malls, but different types of settings "are rushing to emulate the cathedrals of consumption", such as universities, fast food restaurants, souvenir shops, video arcades (Ritzer 2005: x), and even megachurches which offer aerobic classes, bowling alleys, counseling centers, and multimedia bible classes (Ritzer 2005: 23).

Zygmunt Bauman analyzed shopping as a rite of exorcism. People are "running after pleasurable-tactile, visual or olfactory-sensations, or after the delights of the palate, promised by colourful and glittering objects displayed on the supermarket shelves" or "sensations promised by a session with a counselling expert. But they are also trying to find an escape from the agony called insecurity" (Bauman 2000: 81). The crowds gather in the temples of consumption, but not in order 
to talk and sociate, points out Bauman. Encounters in a crowded space are brief and shallow. People don't establish deeper or more complex relationships. However, crowded the place may be, it is not collective, reflects Bauman. "To deploy Althusser's memorable phrase, whoever enters such spaces is 'interpellated' qua individual, called to suspend or tear up the bonds and shed loyalties or put them on a side burner" (Bauman 2000: 97). This fundamental link between the means of consumption and ideology is crucial to understanding the processes of subjectification and desubjectification taking place via the means of consumption, which is itself an apparatus. As demonstrated by Michel Foucault and Giorgio Agamben, apparatuses in a disciplinary society seize the bodies in the very process of their desubjectification. In order to produce new subjects, the apparatuses first split the subject through the negation and at the same time the assumption of the old. The apparatus of the prison, for instance, produces "the constitution of a subject and of a milieu of delinquents, who then become the subject of newand, this time, perfectly calculated-techniques of governance" (Agamben 2009: 20). In a quite similar manner the means of consumption produce the constitution of a subject and a milieu of consumers who become the subject of the calculated technique of governance, altogether with the ultimate objective to accumulate capital and to increase the economic and political power of the social elite.

In 2003 Laibach, the founding art and musical group of the art collective Neue Slowenische Kunst, performed a visit to the shopping mall City Park in Ljubljana. As part of their outfits the group wore a kind of military uniform particularly reminiscent of the Wermacht uniform. The group became known for provoking the public during the disintegration of the Eastern bloc with ambiguous performances with which they addressed the functioning of totalitarian systems. Their interventions were a torment for a society with collective memory of the German and Italian occupation. Within the performance Einkauf (Shopping) they simply took a shopping cart and walked in a military style around the mall, doing their shopping in their uniforms with serious expressions on their faces. Their performance was uncomfortable for the people present in the given context. The consumers felt threatened and security guards were unsure whether or not to stop the intervention. The invisible envelope of the Arcadian environment designed for enjoyment and relaxation was suddenly broken. The action unconcealed the fact that the consumerist space is clearly politically structured in a totalitarian manner, as it does not tolerate any penetration of other ideas, behaviors, rites, or ideologies. The performance showed the parallels between consumer ideology, as well as the functioning of its means of consumption, and political totalitarian systems. The seemingly non-political consumerism is proved to be fundamentally political. Art has, in this case, shocked the present public who was not expecting to come in contact with art in that context. Its function was 
this time to awaken consumers and to unconceal the political structure of the temple of consumption.

Temples of consumption offer "the comforting impression of belonging" (Bauman 2000: 99). Bauman pictured the places as a "floating boat", a "self-contained "place without a place", which is a "purified space". The place had been cleansed of variety and difference; the differences inside "are tamed, sanitized, guaranteed to come free of dangerous ingredients-and so be unthreatening", so that "what is left is pure, unalloyed and uncontaminated amusement" (Bauman 2000: 99). The isolative and the excluding character of the temples of consumption is complete:

The place is well protected against those likely to break this rule-all sorts of intruders, meddlers, spoilsports and other busybodies who would interfere with the consumer's or shopper's splendid isolation. The well supervised, properly surveilled and guarded temple of consumption is an island of order, free from beggars, loiterers, stalkers and prowlers-or at least expected and assumed to be so. (Bauman 2000: 98)

Consumption is related to destruction of critical potential and moral indifference. In 2006 the artist Sašo Sedlaček hit in the core of this problem with his project Beggar. The Beggar is a robot made at home from recycled material, designed to help socially marginalized people. Sedlaček noticed that the huge places of consumption are exclusionary, as there are no homeless people to be found there, whereas poverty is an increasing social problem. Despite replacing historic city centers, these places have not fully assumed the function of an open public space for all (Tratnik 2009: 18). The Beggar was let into the City Center in Ljubljana as a robot collecting money for the homeless. It collected much more than homeless people collect in the same time frame on the street, selling their newspaper Street Kings which is meant to be an alternative to direct begging. This says a lot about the compassion people have toward the poor compared to the sympathies we have towards digital technology. If on the one hand people feel uncomfortable when confronted by poverty and homelessness which make invoke feelings of fear, on the other hand they are attracted to the mechanical or even more with the digital gadgets that they can play with.

The means of consumption rely on the mechanism of seduction. Bauman recognized that the heavy, Fordist-style capitalism, passed over to the light, consumer-friendly capitalism. If the first was the world of the rulers, law-givers, and supervisors who directed other people, the latter preserved authorities but now authorities coexist. The authorities of light capitalism no longer command, but they ingratiate themselves with the chooser; they tempt and seduce (Bauman 2000: 63). Yet in a consumer society everything is a matter of choice except the compulsion to choose. This compulsion grows to an addiction and is thus no longer perceived as a compulsion (Bauman 2000: 73).

After the fall of the Berlin Wall, the former communist European countries started to join the European Union one after another, as to an 
alliance of the European countries with a collective political governance and a foundation in capitalism. In the former communist countries, the shopping centers were quickly built during the transition to capitalism. The phenomenon of consumerism at once struck the population in these countries. People who experienced a shortage of goods under the previous regime and used to smuggle them from other countries where they would go on shopping trips, were suddenly overwhelmed by the richness of the offer, the surplus of commodities that suddenly appeared near their homes. They were enchanted by the means of consumption and the complete experience that shopping at once became. The population, disappointed with the previous ideology, was subject to uncritically accept the arrival of the new capitalist ideology. The directors Vít Klusák and Filip Remunda showed how high the level of seduction and even addiction to shopping was for the Czech population in 2004, with their film project The Czech Dream. They studied the components required for the successful establishment of a shopping mall, apart from its construction, that would draw the consumers to the defined location. Klusák and Remunda built the whole promotion of the coming center; they made out their own appearance, conducted the advertising campaign and even produced a theme song to emotionally attract the consumers. Finally, people arrived many hours before the expected opening of the mall, but the location was just a rural field and instead of wandering in the shopping mall they got a chance to take a walk in the countryside. Many of the people who had arrived expecting to have a shopping experience felt angry. Afterwards, the project triggered rich public discussions as rarely seen regarding consumerism, the role of art and public financing of art, as well as on the political question of joining the European Union, which was current at the time.

In 2003 Sašo Sedlaček collected the advertising leaflets that he had been receiving from the shopping centers, and invited the public to build bricks out of this material in the gallery space (Kapelica Gallery). With a group of colleagues, he then conducted an action: with those bricks they built a wall with which they closed off the entrance of the City Park in Ljubljana. He accompanied the intervention, which he called Just Do It!, by stating that he was only giving back what he had received and had not asked for.

These cases of performative art unconceal the truth of capitalism, its refined hidden mechanisms and ideology, as well as its (side) effects, such as the increase in poverty within the population, ecological pollution due to the hyper-production of goods, shopping centers, and promotional material. Art is, in this case, not experienced through the mechanism of contemplation. Its function is to stimulate critical thinking. This is possible with an intervention of art into the marrow of capitalism, into its means of consumption which is the capitalist means of enchantment. This is an intervention into the Church of capitalism, the sacred environment, where the consecrated ritual of seduction takes place. 


\section{Conclusion}

Jameson's mourning for contemporary art that does not fulfil expectations to be critical towards capitalism is grounded in his ontology of art. His comprehension of true art is built upon Martin Heidegger's concept of art. For Heidegger, art is expected to communicate truth. Heidegger's ontology of the work of art rests upon Hegel's ontology of art, according to which art has the status of representation in the sense that it is established as a secondary reality which is set in relation to the first. As such it functions as a medium, intervened by the artist, which can facilitate the unconcealment of the truth. Jameson's ontology of art did not pay regard to the rising phenomenon of the temples of consumption which are the crucial point for the examination of culture in late capitalism. Jameson did not fully consider the passage of capitalism from the end of the $19^{\text {th }}$ century or the beginning of the $20^{\text {th }}$ century to contemporaneity, or from what Zygmunt Bauman called the "heavy", Fordist-style capitalism, to the light, consumer-friendly capitalism which is signified by the growth of temples of consumption. Jameson, furthermore, did not consider the great changes that art had gone through in the second half of the $20^{\text {th }}$ century, from the representational to the performative mode of art. If he considered art as performative and had searched for its task in relation to the interpellation of the consumer, supported with the specially-designed environments as centers of experience, he might have imagined the possibility of critical art in the context of late capitalism much differently.

\section{References}

Agamben, G. 2009. What is an Apparatuss? Stanford: Stanford University Press.

Baudrillard, J. 1994. Simulacra and Simulation. Michigan: The University of Michigan Press.

Bauman, Z. 2000. Liquid Modernity. Malden: Polity.

Benjamin, W. 2008. The Work of Art in the Age of Its Technological Reproducibility, and Other Writings on Media. Cambridge and London: Harvard University Press.

Corrigan, P. 1997. The Society of Consumption. London: Sage.

Debord, G. 1989. Society of the Spectacle. London: Aldgate Press.

Feagin, S. L. 1995. "Paintings and their Places." Australasian Journal of Philosophy 73 (2): 260-268.

Feuerbach, L. 1855. The Essence of Christianity. New York: Calvin Blanchard.

Hegel, G. W. F. 1975. Hegel's Aesthetics. Lectures on Fine Art. Oxford: Oxford University Press.

Heidegger, M. 1993. "The Origin of the Work of Art.” In Basic Writings. San Francisco: Harper: 139-212.

Jameson, F. 1991. "The Cultural Logic of Late Capitalism." In Postmodernism, or, the Cultural Logic of Late Capitalism. London, New York: Verso: $1-54$. 
Mandel, E. 1972. Der Spätkapitalismus. Frankfurt am Main: Suhrkamp.

Moore, A. 1980. "Walt Disney World: Bounded Ritual Space and the Playful Pilgrame Center." Anthropological Quarterly 53 (4): 207-218.

O'Doherty, B. 2000. Inside the White Cube: The Ideology of the Gallery Space. Los Angeles: University of California Press.

Ritzer, G. 2005. Enchanting a Disenchanted World, Pine Forge Press. Revolutionizing the Means of Consumption. 2nd edition. Thousand Oaks: Pine Forge Press (Sage).

Tratnik, P. 2009. "Brkljanje, ki sproti rešuje probleme. Pogovor s Sašem Sedlačkom.” Maska XXIV (119-120): 14-19.

Tratnik, P. 2019. "Umetnost kot investicija: institucija umetnosti v službi umetnostnega trga." Annales: anali za istrske in mediteranske študije, Series historia et sociologia 29 (3): 473-484.

Zepp, I. G. 1986. The New Religious Image of Urban America. Shopping Mall as Ceremonial Center. Westminster, MD: Christian Classics, Inc. 